\title{
Weaving New Beginnings in Philippine Bureaucracy: A Closer Look on Senate Bill 2616 (Anti-Political Recommendations Act)
}

\author{
Lorraine Kay P. Villaluz
}

\begin{abstract}
Recruitment of government employees through merit system is a big dilemma being faced by many government offices in the Philippines especially after local and national elections. Elected officials used their victory to reward supporters to government employment irrespective of supporters' qualifications. Such a practice has ignored the civil service rules and regulations regarding recruitment and has compromised the quality of public services delivered to the constituents in many local and provincial locations in the country. Despite attempts to reduce such political culture in the past, no substantial indications of change has been recorded yet, instead, politically employed personnel tended to perform poorly affecting bureaucracy. Passing Senate Bill 2616 otherwise known as "Anti-Political Recommendations Act" into law vis-a-vis strict compliance to mandates of Civil Service answers the need to curb, if not completely wipe out the wrong culture of political recommendation for government offices. It may augment the standard and quality of services being provided to the constituents through a rigorous, transparent and correct employment processes. More so, this paper explores the necessity of enforcing anti-political recommendation bill into law for an accountable, fair and transparent Philippine bureaucracy.
\end{abstract}

Index Terms-Anti-political recommendations act, merit system, Philippine bureaucracy, senate bill 2616.

\section{INTRODUCTION}

"Public Office is a public trust" says Section 1, Article XI of the 1987 Philippine Constitution that formed the core of Senate Bill 2616 or the Anti- Political Recommendations Act. Senator Miriam B. Defensor -Santiago introduced this bill at the Fourteenth Congress of the Philippines. This bill seeks to penalize misconduct of public officials specifically in reference to using their office as rewards to their supporters or to influence the employment of their supporters.

This paper seeks to enlighten Filipino masses in supporting this Bill into law so that genuine democracyhonest and fair delivery of public services will be felt all throughout the country specifically in areas that are in dire need of these resources. Utilizing a narrative-descriptive approach the researcher attempts to:

- Call upon the Congress of the Philippines to pass Senate Bill 2616 into law vis-à-vis Sec.1, Article XI of the 1987 Philippine Constitution

Manuscript received September 24, 2013; revised November 28, 2013. Lorraine Kay P. Villaluz is with the University of the Philippines Tacloban College, Tacloban City, Philippines (e-mail: lovingcookiesncreme28@gmail.com).
- Discuss Senate Bill 2616 as a key in re-shaping Philippine bureaucracy and curbing, if not to completely eradicate the practice of political recommendations

- Encourage Filipino masses to invoke their rights; challenge the local and national officials to act accordingly- just, honest and fair use of public funds for nation's socio-political and economic advantages and not their own

Through this paper the researcher hopes to enlighten the Filipino electorate on the need of invoking their rights stipulated in the Constitution and to ensure such rights is the source of informed, empowered and active Filipino citizens. In like manner, the researcher aims to awaken those in the academe and both public and private offices to be proactive, lead our nation's transformation. The national issues should not be left to the legislators and a few good men but every Filipino's fight. Wiping out political recommendations maybe cumbersome, but if all will support the implementation of said bill into law, true bureaucracy then will be within reach. It is vital to uphold the real essence of bureaucracy as this is what makes up genuine democracy. Twenty-seven years of regime change, yet the slow -paced efficiency in governance seems to grow fainter alongside citizen's passive political participation.

Using secondary data from local and foreign sources, this paper is divided into three sections. The first part introduces Senate Bill 2616 and its modifications from the time it was first endorsed in Fourteenth Congress (2008) and the modifications during the Sixteenth Congress (2013). The second part invite readers especially every Filipinos to support the implementation of this bill into law through a case analysis on its essence. And lastly, it persuades Filipinos to open their eyes on the nation's plight through the recommendations cited.

The recent case of Maria of $Z$ Office should be an eye opener to Filipinos. Let us act now. Ensure that public funds are allocated for promotion of everyone's welfare and not for personal gains. These public funds could have been allocated to lessen calamity effects in our nation; hence, it aided them to live a luxurious life instead. Will Filipinos allow Maria to continue this business or will Filipinos stand up and fight for what is due them? This is a question, only a reflecting Filipino can answer. The researcher believes that $21^{\text {st }}$ century Filipinos are empowered individuals. They just need a push and this is it.

\section{Getting ACQuainted with SenAte BiLl 2616}

Section 1, Article XI of the 1987 Philippine Constitution provides: "Public Office is a public trust. Public Officers 
and employees must, at all times, be accountable to the people, serve them with utmost responsibility, integrity, loyalty and efficiency, act with patriotism and justice and lead modest lives [1]."

This provision urged Senator Miriam B. DefensorSantiago to instigate Senate Bill 2616 during the second session of the Fourteenth Congress with the title "An Act to Prohibit the Use, Solicitation and Offer of Recommendations for Purposes of Appointment, Promotion, Assignment, Transfer, or Designation, Interim or Otherwise, of Public Officer or Employee." This Bill is given the short title of "Anti- Political Recommendations Act [2]."

The tenet of public office is a public trust, the outbreak of misuse public funds and the alleged 'padrino system' in QRS Office fostered the Senator to pioneer said Senate Bill 2616. "Why should a senator or congressman meddle and influence how an agency of the executive branch hires its employees? If the person you backed turns to be corrupt, what does it say about you as a politician [3]? goes Senator Santiago's inquiry that leads to the birth of such Bill as the Senator's response to the growing menace of how public officials influence recruitment process by pursuing acts of "political recommendations" for their supporters with the hope that such will be supported by the Filipinos and possibly pass it into law. The run through of political recommendations impede bureaucratic practice since officials who were then lower in rank will be compelled to obey orders by their superiors.

Her action to reduce political patronage is seconded by Senator Francis Escudero who issued Senate Resolution 124, calling for a joint investigation on the purportedly influential personalities behind one of the Philippine government offices [4], highly exposed through the case of Maria of $\mathrm{Z}$ office for misuse of public funds.

More so, the Senator mentioned, "by enacting a law that punishes the acts of making and soliciting political recommendations, we would be able to strengthen our bureaucracy by granting the appointing agencies their rightful discretion over their employee activities, which include appointment, promotion, assignment, transfer or designation, interim or otherwise, and making sure that such decisions are made without undue political influence [5]." Hence, the Filipinos commitment on supporting the passage of Senate Bill 2616 into law may reduce; if not completely end the practice of political recommendation.

Furthermore, Senator Escudero cited it is high time to hold public servants accountable as they probe the issue of patronage politics in government offices. He reminded public servants that the work of persuading, inducing or influencing any other public officer is punishable under Republic Act 3019 or the Anti- Graft and Corrupt Practices Act as a corrupt practice and punishable under this law [6] but still, it did not eliminate the wrong practice of political recommendation. It is high time to indeed have one concrete law that will punish offenders and finally utilize public offices for common good.

Senate Bill 2616 could have been phenomenal except line 14; Section 8 of said proposal appears ineffectual to the researcher. Such provision states,
- "Any person in violation of any of the provisions of this Act shall be punished by a fine of not less than neither one hundred pesos nor more than one thousand pesos, or by imprisonment not exceeding one year, or by both such fine and imprisonment, at the discretion of the Court. The violation of said section proven in a proper administrative proceeding shall be sufficient cause for removal or dismissal of a public officer, even if no criminal prosecution is instituted against him" [7].

The monetary value between one hundred Philippine pesos (100 Php) to one thousand Philippine pesos (1000 Php) is very minimal, contrary to how easy perpetuators can get away with fraud. In like manner, one year imprisonment is inadequate especially how politics affect recruitment process.

\section{SiXteEnth Congress SEnAte BILl 2616 Alteration}

Giving prominence to public office as a public trust Senator Santiago felt the need to curb if not wipe out political recommendations in the first regular session of the Sixteenth Congress. A formidable monetary sanctions for Senate Bill 2616 is now in place in Section 8 which states,

- "Any person in violation of any of the provisions of this Act shall be punished by a fine of not less than one thousand pesos $(\mathrm{P} 1,000.00)$ nor more than thirty thousand pesos $(\mathrm{P} 30,000.00)$, or by imprisonment not exceeding one (1) year, or both such fine and imprisonment, at the discretion of the Court. The violation proven in a proper administrative proceeding shall be sufficient cause for removal or dismissal of a public officer, even if no criminal prosecution is instituted against such officer."

The increase on the penalties was a reaction to the issue of patronage politics affecting recruitment process as well as promotions of high ranking bureaucrats at QRS office. Santiago shared further, that such procedure "tends to bypass more qualified individuals to government positions in favor of ones with better political connections." Thus, there is a need to go back to merit system [8].

This led the Filipinos to question the significance of Public office being a public trust. Fr. Joaquin J. Bernas, S. J. explained that being accountable to the public meant to acknowledge that the official is the people's representative since Philippine government is a representative government. To add, Bernas narrated further that the provision emphasized that even the official is independently wealthy he should not flaunt these riches to the public [9]. Apart from the issue of accountability among public officials Senate Bill 2616 advocates a going back to merit system [10] in Philippine Bureaucracy.

Contrary to the above-mentioned, Philippine bureaucrats live extravagantly, own luxurious properties here and abroad. Linking this with the recent issue with one of the essential offices in the Philippines, we shall call it Z Office manage by "Maria". The breakthrough of misuse public funds led Filipinos in general to protest and demand for better civil service policies and a going back to merit system. Maria's example is formidable; thus the requisite of legalizing Senate Bill 2616 to obligate her likes to repay Filipinos of public funds through penalties sanctioned in said Bill. 


\section{Pork ANd I MARia's Z OfFice CASE: Senate BiLl 2616 CASE ANALYSIS}

August 5, 2013 [10] - The Filipinos were agitated by the expose of a relative of Maria and a former employee at her $\mathrm{Z}$ office as to how Maria made used of the priority development assistance fund of some legislators for her own advancement. The narrative was brought about by the latter's dismissal. Maria was crying foul and vowed she does not even know "what pork issue is all about." Furthermore, she swore that the family's wealth is rooted from her mother's side who owned a non-profit, nongovernment organization for years; that when her better half retired, they invested into businesses abroad and this began the transition of their way of living.

Whatever the truth behind these informations, the best part of this case is that Maria and her better half is already in the government's hand. The moral lessons of this story is that no Maria can get away if all will be supportive of correcting a mistake by implementing laws instead of succumbing to political connections. Second, the nation is given the chance to ponder on the necessity of priority funds among legislators- whether or not to completely abolish it or have it on meritous grounds. This is a classic call of empowerment and unity among Filipinos. May the EDSA 1 spirit be with us all as we reflect onto the "Pork and I; Maria's Z office story."

Also it is time to revamp Philippine bureaucracy vis- avis Civil Service examinations along with other qualifications as set forth by respective agencies with the applicant's consideration be left to sole discretion of these agencies. Rod Hague and Martin Harrop provided that bureaucracy when introduced by Max Weber involves carefully defined task, division of tasks, authority is impersonal and decisions were reached after thorough consideration of applicable rules and people were recruited based on proven or at least potential competence [11]. Thus, in the Philippines the creation of Civil Service Commission meant to mirror merit system through the administration of Civil Service examinations that assist in measuring the credibility of civil servants other than the requirements stipulated by hiring agency and those required by other laws of the land. A clear example of merit system is Presidential Decree 907 or the Civil Service Eligibility for Honor Graduates. This exempts those who graduated with Latin Honors from subjecting themselves to the Civil Service examination Professional level as part of the recruitment process in any government positions in the country but may subject themselves to further qualifications set by agencies they are applying for. On the contrary, the battle is no longer about competence but political connections; Hence, the need to truly pass this Senate Bill 2616 into law. Otherwise, we will wake up with spoils system as the bureaucratic theme of our nation.

With this, Filipinos challenge the Congress to do the functions entrusted to them. As of this writing, Congress is reviewing this Bill, does a background check on the likes of Maria. The best part is that even the President of the Philippines is one with Congress in the quest to concretize, review and execute stricter policies for bureaucracies alongside with Civil Service Commission. The President, in his State of the Nation Address (SONA) called on passage of Civil Service Code that will also strengthen merit system in Philippine bureaucracy.

\section{CONCLUSION}

Filipinos should not wait on Pork and I repeat. Those in the Academe, private and public sectors should urge Congress of the Philippines to pass Senate Bill 2616 into law. This can curb, if not entirely end the culture of political recommendations. This is the root of spoils system in the bureaucracy, thus the need to cut it. Until and unless this is acted upon by Filipinos, some public officials will continue their wrong practice and our nation will continue to suffer.

Lobbying for a cause is surely an edge against those who continue to influence bureaucracy, the wrong way. Let this be stopped by being united. The Million People March should not be a onetime newsworthy activity but rather a Philippine history. The researcher believes that an informed Filipino will be politically active. Let us start now and take hold of our nation's socio-political and economic transformation.

\section{RECOMMENDATIONS}

The lifestyle check for all public officials should be revitalized to ensure all public officials live life in accordance to what is expected of them through Section 1, Article XI of the 1987 Philippine Constitution. A stronger audit for their statement of assets and liabilities should form part of this measure. Doing so, may prevent the repeat of misuse of public funds.

The revamp on Philippine Bureaucracy with Civil Service Commission on the lead ensures an accountable, fair and honest bureaucracy. Merit system is expected to be incorporated to recruitment procedures. The Filipinos is now assured of qualified and effective bureaucrat who may fear the tendencies of corruption due to the penalties incorporated to Senate Bill 2616 should it be legalized.

The legalization of Senate Bill 2616 into law by the Philippine Congress may finally curtail the practice of political recommendations that impair the bureaucratic process; that Filipinos be vigilant and if such Bill remained around the corner, Filipino people will opt to Initiative as their hope to put laws into their own hands. Such will move the officials to be proactive and forever protect the general welfare.

\section{REFERENCES}

[1] J. Bernas, The 1987 Philippine Constitution, A Comprehensive Reviewer, Quezon City, Philippines: 2006, pp. 440.

[2] M. Defensor-Santiago. (September 2008). Anti- Political Recommendations Act. Second Regular Session. Fourteenth Congress. Senate Bill 2616. Section 8, line 14 SB 2616. [Online]. Available:

http://www.senate.gov.ph/lis/bill_res.aspx?congress=14\&q=SBN2616 and http://www.scribd.com/doc/157975768/Anti-PoliticalRecommendations-Bill opened on September 14

[3] A. Fernandez. (August 2013). Sen. Miriam files anti- political recommendations bill vs 'padrino system. [Online]. Available: http://www.gmanetwork.com/news/story/320596/news/nation/senmiriam-files-anti-political-recommendations-bill-vs-padrino-system

[4] M. Ager. (July 2013). Senate probe sought into 'Customs' padrino system. [Online]. Available: 
http://newsinfo.inquirer.net/455193/senate-probe-sought-intocustoms-padrino-system

[5] C. Mendez. (August 2013). Bill seeks to criminalize padrino recommendations.

[Online]. Available: http://www.philstar.com/headlines/2013/08/05/1053491/bill-seekscriminalize-padrino-recommendations

[6] M. Ager. (July 2013). Senate probe sought into 'Customs' padrino system. [Online]. Available: http://newsinfo.inquirer.net/455193/senate-probe-sought-intocustoms-padrino-system

[7] M. Defensor-Santiago. (September 2008). Anti- Political Recommendations Act. Second Regular Session. Fourteenth Congress. Senate Bill 2616. [Online]. Available: http://www.senate.gov.ph/lis/bill_res.aspx? congress=14\&q=SBN2616 opened on January 30, 2013 at 5:49 PM

[8] J. Codilla. (August 2013). Miriam's Anti- political Recommendations Bill. [Online]. Available: http://www.zambotimes.com/archives/news/71645-Miriams-Antipolitical-Recommendations-Bill.html

[9] J. Bernas, The 1987 Philippine Constitution, A Comprehensive Reviewer, Quezon City, Philippines: 2006, pp. 440.

[10] C. Yamsuan. (August 5, 2013). Bill aims to stop "padrino" set up. Philippine Daily Inquirer. [Online]. pp. A1-A23. Available: http://newsinfo.inquirer.net/458513/santiago-files-bill-to-stoppadrino-system-in-govt-appointments

[11] R. Hague and M. Harrop, Comparative Government and Politics, an Introduction, $8^{\text {th }}$ ed., New York, Palgrave Macmillan. 2010, pp.345346.

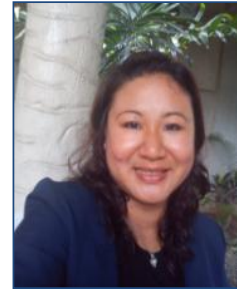

Lorraine Kay P. Villaluz is a member of the Division of Social Sciences at the University of the Philippines Tacloban College serving as a political science faculty and is at present a member of Philippine Political Science Association (PPSA) .She is also a human rights trainer for Region X. She finished master in Political Science in 2009 from University of San Carlos, Cebu City, Philippines. She took up Bachelor of Arts major in Political Science from Notre Dame of Marbel University, Koronadal City, Philippines and graduated a Cum Laude. With this, she is awarded Presidential Decree 907 (Civil Service Eligibility for Honor Graduates) Apart from the Academe, she also worked as a travel specialist and excelled on this too. She is the author of the article "Equal Political Opportunities through Senate Bill 2649: A Challenge to Reduce Political Dynasty in the Philippines," included for publication in Contemporary Social Sciences, Vol. 22, No. 3 and 4 (July-December 2013)/ Journal of National Development, Vol. 26, No. 2 (Winter 2013). Her Research interests are Comparative Governments, Constitutions, Elections, Gender and Development, Gender Issues, Governmental Practice/ Systems, Human Trafficking, Human Rights, Law, Mindanao Politics, Politics, Structure of Governments, Rule of Law. 